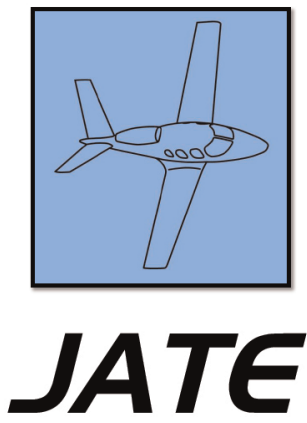

Journal of Aviation Technology and Engineering 4:1 (2014) 32-39

\title{
Establishing a Benchmark of Fuel Efficiency for Commercial Airline Operations
}

\author{
Samuel Chandra, Chetan K. Chitgopeker, Ben Crawford, John Dwyer, and Yi Gao \\ Swinburne University of Technology (Australia)
}

\begin{abstract}
Fuel efficiency is vital for commercial airlines as fuel is one of the most costly items for airline operations. This study aims to compare fuel efficiencies of selected airlines around the globe and to build a benchmark of fuel efficiency that can be referred to by airlines. By using data on fuel consumption and traffic output collected from various sources including airline annual reports, environmental reports and sustainability reports, this study calculated fuel efficiencies measured by liters of fuel consumed per revenue tonne kilometer (RTK) for the selected airlines in the calendar year 2011 or financial year 2010-2011. Airlines were also compared and ranked by their respective fuel efficiencies. It was found that, depending on whether the passenger equivalent freight mass (PEFM) was $91 \mathrm{~kg}$ or $160 \mathrm{~kg}$, the average fuel efficiency of the airlines studied is $0.4 \mathrm{~L} / \mathrm{RTK}$ or $0.278 \mathrm{~L} / \mathrm{RTK}$, respectively. Variances in fuel efficiency among airlines from different regions and airlines of different business models were also found by this study.
\end{abstract}

Keywords: fuel efficiency, airline operations

\section{Introduction}

The finite nature of oil, and thus aviation fuel, is increasingly becoming a limiting factor for the aviation industry: a direct result is the inevitable increase in prices that is associated with scarcity. This presents an incentive for the industry as a whole to focus on improvements in fuel efficiency (ATAG, 2013; Grose, 2013). The International Air Transport Association (IATA) aims to improve fuel efficiency across the industry by $1.5 \%$ per annum until 2020, while the International Civil Aviation Organization (ICAO) is striving for a 2\% per annum improvement until 2050 (Commonwealth

\footnotetext{
About the Authors

Samuel Chandra, Chetan K. Chitgopeker, Ben Crawford, and John Dwyer are recent graduates of the Department of Aviation, Swinburne University of Technology (Australia). Correspondence concerning this article should be sent to samuel.chandra01@gmail.com.

Yi Gao received his Ph.D. in aviation management from Purdue University in 2010. He is currently a lecturer (equivalent to tenure-tracked assistant professor in the American system) at Swinburne University of Technology. His research interests include aviation security, air transportation, airline operations, and airline marketing.
} 
of Australia 2012, p. vi). Modern jet aircraft are over 70\% more efficient than similar aircraft that were flown during the beginning of the jet era (ATAG, 2013); however, this alone does not constitute the solution to achieve ICAO and IATA targets.

There are three areas in which fuel efficiency improvements are being sought by the aviation industry: aircraft hardware, operational practices and load factors. In the first area, aerodynamic features such as winglets, riblets, and engines with higher bypass ratios are installed on modern jets to reduce fuel burn. Operational practices include air traffic management procedures such as performance-based navigation, continuous descent approaches and various air traffic flow management systems, alongside improved aircraft operating procedures such as single-engine taxi. As significant technological breakthroughs in power plant and airframe technology are becoming increasingly difficult to come by, the manner in which airlines operate their fleets is where fuel usage can be optimized and where subsequent cost reductions will occur. This is coupled with a drive from society to improve efficiency as emissions targets are being introduced on both a national and enterprise level (Kling \& Hough, 2011).

The basic concept of efficiency is expressed as output divided by cost (Hileman et al., 2008), in which output is the amount of traffic volume an airline undertakes in terms of passengers carried and freight transported, and cost is the amount of input such as fuel or money used to achieve the output. This makes it important to judiciously determine how both airline output and cost are expressed in calculations. An appropriate metric for output is Revenue Passenger Kilometers (RPK), as it is the most appropriate way to show the total production of an airline, rather than Available Seat Kilometers (ASK), which is more a measurement of capacity (Keisling, 2010). Further, a unique consideration in aviation is that freight and passengers are routinely carried in the same vehicle (Hileman et al., 2008), thus an equivalent freight mass must be determined per passenger so that the value in terms of carrying both passengers and freight can be uniformly expressed with one variable. The various types of costs to an airline include time taken, energy used, fuel used and carbon dioxide emitted (Kling \& Hough, 2011; Hileman et al., 2008). Hileman et al. (2008) and Peeters et al. (2005) use MJ (energy) as a cost, arguing that it evens out the comparison when dealing with different energy densities of various fuels. However, studies such as Nielsen (2003) and McCartney (2010), as well as this study, use fuel as a cost as it is a commonly used and straightforward cost metric in aviation.

Methods to determine airline output and cost can be categorized in two ways: the top-down approach and the bottom-up approach. The former approach is employed by McCartney (2010) and Peeters et al. (2005). Large aggregations of flights flown, passengers, and fuel burned for multiple airlines are used to find an average of fuel used per ASK or RTK. Zeinali et al. (2013) used statistical methods such as regression to link airlines' fuel consumption to Revenue Passenger Miles (RPM) and total departures. However, their study did not consider freight traffic at all, which limits the generalizability of their method to be applied to airlines from regions other than the US. On the other hand, the bottom-up approach is suitable if analyzing single types of aircraft and comparing them to each other using published manufacturer data (Peeters et al. 2005). This approach can be extremely time consuming and impractical when calculating fuel efficiency of an airline operating tens or even hundreds of aircraft. Data that includes an entire mission profile is important as it takes into account various fuel burns in all phases of flight, whereas an instantaneous measurement only specifies a particular moment in time in the calculations and therefore, according to Owen (2008), is not fully realistic.

Although the trend of improved fuel efficiency has been achieved over the jet era (Owen, 2008), modern jets are only as efficient as the last propeller-powered airliners (Peeters et al., 2005), albeit being far more expedient. Owen (2008) concluded that the majority of gains were experienced in the first ten years of the jet era: since 1981, a much slower rate of change has occurred due to the fact that step changes in hardware have been rarer. Owen also stated that the main drivers of efficiency in the last six years are improving load factor and fuel per ASK. Berdowski et al. (2008) made the understandable point that standard passenger mass has increased over time and so it is important to use accurate and applicable figures in assumed passenger mass. These findings concur with those by Kling and Hough (2011), stating that the more passengers and freight that an aircraft carries, the better its efficiency. McCartney (2010) suggested that the most and least efficient U.S. airlines were JetBlue and Delta, respectively, all the while neglecting the role that load factor plays in efficiency. This has been pointed out by Keisling (2010) and the Danish EPA, who had already taken this into account and found that the most efficient airlines globally were Lufthansa and Premair, while the least efficient were Braathens and SAS (Nielsen 2003). To the best knowledge of authors of this study, Nielsen (2003) was the last global airline fuel efficiency study taking into account load factor. Data for this study was sourced largely from 1998. Thus, research in this area appears to be timely.

The aim of the current study is to develop a method and a metric by which the fuel consumption of an airline can be compared against its output. In addition to this objective, fuel efficiencies of nominated airlines from around the world will be calculated and ranked, and reasons for differences will be discussed. By providing a means by which airlines can compare their own fuel efficiencies against those of their peers in the airline industry, it is anticipated that airlines may use the result of this study as a reference and act on any inefficiencies to achieve better fuel efficiency and operational cost savings. 


\section{Method}

This study used quantitative methods to calculate and compare fuel efficiencies of selected airlines. A total of 12 airlines were selected to represent airlines of different regions and of different business models (full service and low cost). In order to present a realistic global model, the number of airlines selected from each region is representative of global passenger movements by volume (Amadeus, 2013). These airlines are Air China (group), Singapore Airlines, Air France/KLM (group), British Airways, Lufthansa, RyanAir, SAS, American Airlines (pre-merger with US Airways), Southwest Airlines, United Continental Airlines (group), LATAM (group), and Qantas (group).

To reduce inconsistency, data used to calculate fuel efficiency was sourced only from reports or publications published by the airlines directly or through annual filings to government bodies, based on the assumption such sources would provide accurate and trustworthy data. The collection of data came primarily from annual reports, sustainability reports, and corporate social responsibility reports of selected airlines as detailed by Appendix A. Data collected from these sources included actual published figures for total fuel consumption, RPK and RTK. In order to perform a fuel efficiency calculation, at least one of the following data sets in Table 1 needed to be available for each airline. The data collected was for the calendar or fiscal year of 2011, depending on availability of data from individual airlines. It was assumed in this study that average fuel efficiencies of selected airlines remained relatively stable in two adjacent years; therefore, up to a six month time difference exists, depending on the data source (fiscal or calendar year) utilized. These differences have a negligible effect on the calculations and results of this study.

This study used fuel consumption per RTK as the metric for fuel efficiency because it is the standard measure of airline fuel efficiency used by ICAO and is relatively straightforward to calculate (Commonwealth of Australia, 2012). Units used in measurement were liters for fuel consumption, and Revenue Tonne Kilometer (RTK) for traffic output (passenger and freight combined). If necessary, fuel mass was converted from pounds to liters.

RTK (Total) in this study is the total traffic output of passengers and freight combined. Conventionally, RTK is reported only for freight transport, and Revenue Passenger Kilometer (RPK) is used to indicate the volume of passenger transport. Due to the difference in units for measuring passenger and freight traffic, RPK and RTK cannot be directly combined. As such, the primary technical challenge of this study is to calculate the total traffic volume for selected airlines.

When combining passengers and freight, the equivalent mass of a passenger must be determined in order to find RTK (Total). The standard passenger weight used by CASA, as published in the Civil Aviation Advisory Publication (1990), is $77 \mathrm{~kg}$, which does not account for baggage. Other reports use the standard 2007 ICAO passenger weight of $91 \mathrm{~kg}$; however, this also does not take into account baggage (Owen 2008, p. 7). If bags are included, European figures put the average passenger weight at $105 \mathrm{~kg}$ (Berdowski et al., 2008, p. 88). These standards do not include all the extra mass that a passengerconfigured aircraft must carry such as a seat, safety equipment and cabin crew. Peeters et al. (2005, p. 35), therefore, described a more inclusive way of calculating this extra mass, deriving a figure of $160 \mathrm{~kg}$.

This study firstly used the Passenger Equivalent Freight Mass (PEFM) of $160 \mathrm{~kg}$ in the calculation. One tonne divided by $160 \mathrm{~kg}$ is 6.25 ; therefore, $6.25 \mathrm{RPK}$ is the equivalent of one RTK, and one RPK equals 0.16 RTK. The equation to calculate RTK (Total), which combines both passenger and freight output is

$$
R T K(\text { Total })=R T K(\text { Freight })+0.16 R P K
$$

Once collected data were converted into the standardized units of liters and RTK (Total), the efficiency metric of L/RTK was calculated by using the efficiency equation

$$
\text { Fuel Efficiency }=\frac{\text { Liters offuel consumed }}{\text { RTK (Total })}
$$

Additionally, a separate set of calculations was made by using a PEFM of $91 \mathrm{~kg}$, which is the ICAO standard passenger mass as discussed above. This was done to provide a basis for comparison between the two assumed passenger weights and to provide an alternative view of the results.

\section{Results}

Results of the fuel efficiency calculation, measured by L/RTK, are provided in Figure 1 and Table 2, displaying results using both the 91 and $160 \mathrm{~kg}$ PEFM. Note that in

Table 1

Formats of available data.

\begin{tabular}{llll}
\hline & Traffic Type & Data Set 1 & Data Set 2 \\
\hline Fuel Consumption & Passenger & Jointly reported & Jointly reported \\
& Freight & & Jointly reported \\
Traffic Volume (Output) & Passenger & RPK & RTK \\
& Freight & as RTK/unit of fuel & \\
\hline
\end{tabular}




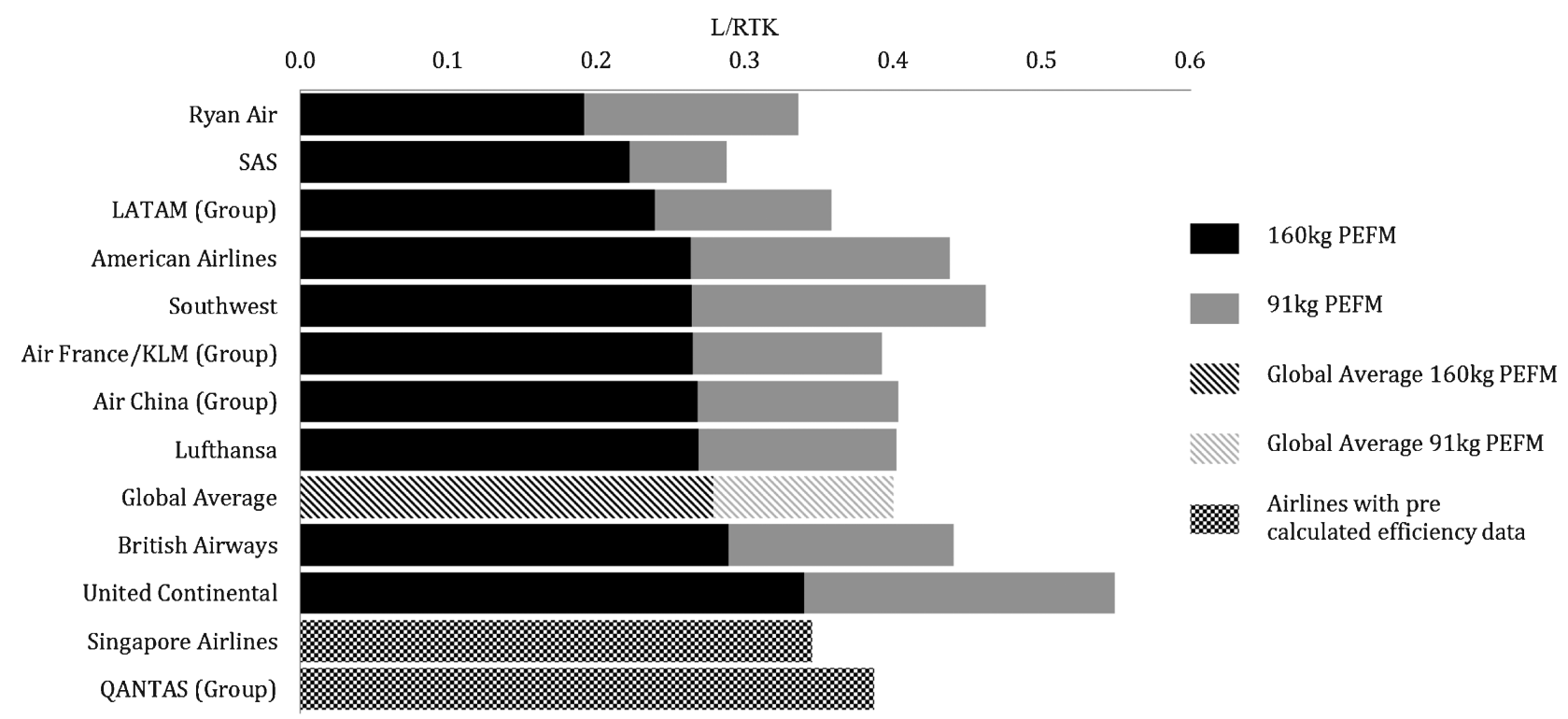

Figure 1. Fuel efficiency of the selected airlines.

Figure 1 and Table 2, the lower the number, the more fuelefficient the airline is. Airlines represented with a chequered pattern are those which published efficiency data directly, thus making it unnecessary to carry out any calculations for them. It should also be noted that, while Qantas and Singapore Airlines are at the lower end of the efficiency spectrum using a PEFM of $160 \mathrm{~kg}$, they are ranked closer to the global average when using the PEFM of $91 \mathrm{~kg}$.

Figures 2 through 4 provide an alternative categorization of fuel rankings from a number of different perspectives including regional grouping, fleet size and freight proportion. Fleet size and freight proportion data were collated from the same sources as the fuel consumption and RTK data: i.e., annual reports, sustainability reports and CSR reports. In Figure 3, Europe is shown to be the most efficient region using both values of PEFM. The relative ranking of the rest of the world (ROW) and North America varies, dependent upon which PEFM value is incorporated into the calculations. Table 2 also displays the average efficiencies for North America, Europe, ROW and the global average.

To ensure the accuracy and reliability of this study, the calculated efficiencies had been verified against three sources, a Brighter Planet study (Kling \& Hough, 2011, p. 17) that examined global airline $\mathrm{CO}_{2}$ emissions, a Danish Environmental Protection Agency study (Nielsen, 2003, p. 85 ) which was the latest available study on global airline fuel efficiency, and an Australian Department of Infrastructure

Table 2

Rankings of airlines by fuel efficiencies.

\begin{tabular}{|c|c|c|c|c|c|}
\hline \multicolumn{3}{|c|}{ Using $160 \mathrm{~kg}$ PEFM } & \multicolumn{3}{|c|}{ Using $91 \mathrm{~kg}$ PEFM } \\
\hline Rank & Airline & L/RTK & Rank & Airline & L/RTK \\
\hline 1 & Ryan Air & 0.191 & 1 & SAS & 0.287 \\
\hline 2 & SAS & 0.222 & 2 & Ryan Air & 0.336 \\
\hline 3 & LATAM & 0.239 & 3 & Singapore Airlines & 0.345 \\
\hline 4 & American Airlines & 0.260 & 4 & LATAM & 0.358 \\
\hline 5 & Southwest & 0.264 & 5 & QANTAS (Group) & 0.387 \\
\hline 6 & Air France/KLM (Group) & 0.265 & 6 & Air France/KLM (Group) & 0.392 \\
\hline 7 & Air China (Group) & 0.268 & & Global Average & 0.400 \\
\hline \multirow[t]{2}{*}{8} & Lufthansa & 0.268 & 7 & Lufthansa & 0.402 \\
\hline & Global Average & 0.278 & 8 & Air China (Group) & 0.403 \\
\hline 9 & British Airways & 0.289 & 9 & American Airlines & 0.438 \\
\hline 10 & United Continental & 0.340 & 10 & British Airways & 0.440 \\
\hline 11 & Singapore Airlines & 0.345 & 11 & Southwest & 0.462 \\
\hline \multirow[t]{5}{*}{12} & QANTAS (Group) & 0.387 & 12 & United Continental & 0.549 \\
\hline & Regional Averages & & & Regional Averages & \\
\hline & European average & 0.247 & & European average & 0.371 \\
\hline & North America average & 0.289 & & ROW average & 0.373 \\
\hline & ROW average & 0.310 & & North America average & 0.483 \\
\hline
\end{tabular}




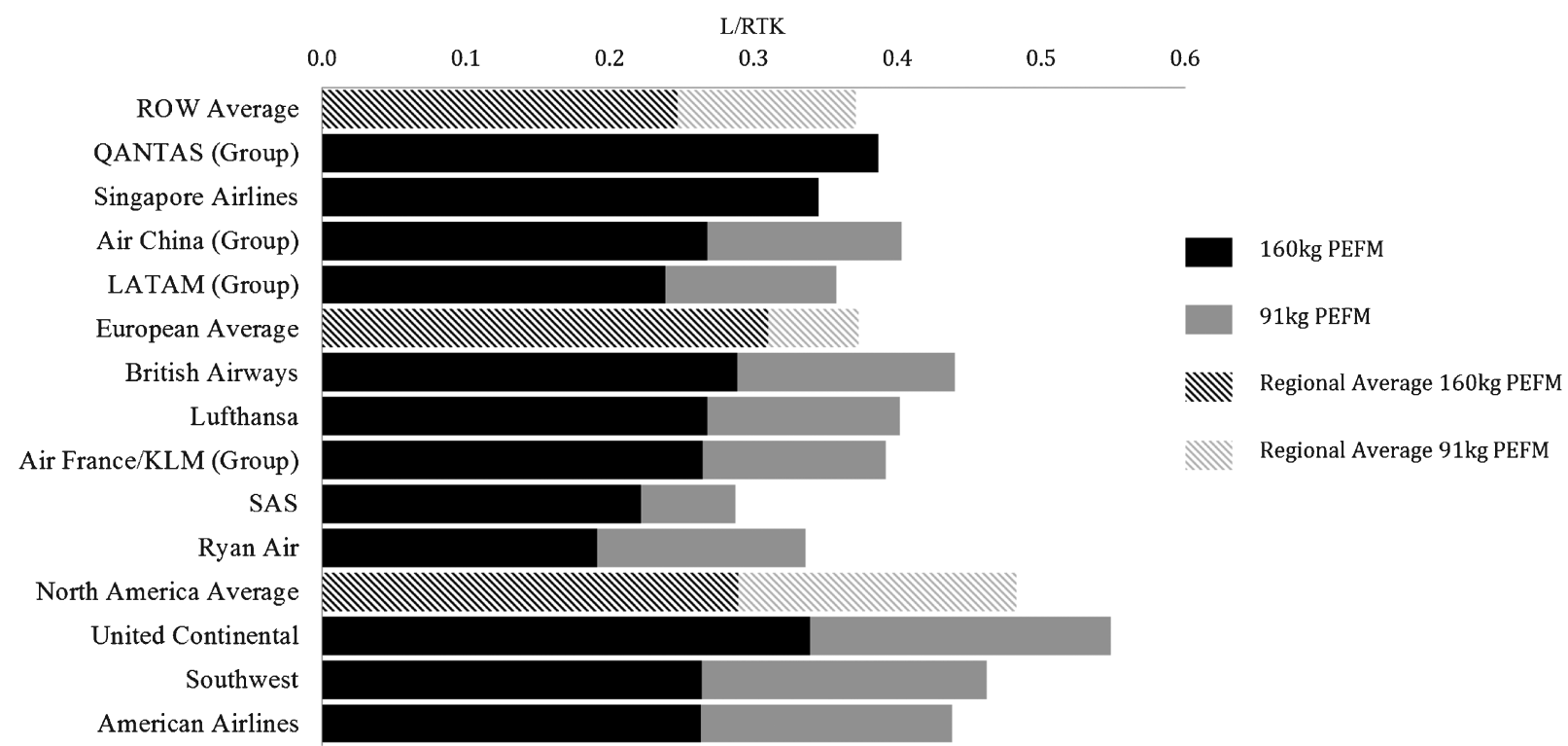

Figure 2. Airline fuel efficiency comparison by region.

and Transport report (Commonwealth of Australia, 2012, p. 10) that cited an Australian average fuel efficiency of 0.37 L/RTK. In general, the rankings here were found to be moderately similar to the first two sources. These variances could be possibly caused by sampling difference as well as efficiency gains that had been achieved by the airline industry in the last decade. While analysis using a PEFM of $160 \mathrm{~kg}$ resulted in the actual efficiency figures only loosely reflecting the findings in the existing studies, the subsequent incorporation of a PEFM of $91 \mathrm{~kg}$ had reached results that are far more closely aligned with the above studies.

\section{Conclusion}

The current study has provided a method of using publicly available data to estimate aircraft operating efficiencies. Calculations and comparisons in this study clearly demonstrate the variance of fuel efficiency among airlines across different regions and different business models. Airlines could use the results of this study as a reference to identify their relative positions in the fuel efficiency ranking by comparing themselves to airlines of similar regions and business models.

The average fuel efficiency varied depending on the PEFM used in the calculations. Originally it was anticipated that using a PEFM of $160 \mathrm{~kg}$ would generate a more accurate estimation of fuel efficiency based on the assumption that $160 \mathrm{~kg}$ takes into consideration more factors such as the weight of passenger seats, which represents the reality of passenger operations. However, the calculated average fuel efficiency using $160 \mathrm{~kg}$ PEFM was slightly higher than the published Australian average (Commonwealth of Australia, 2012, p. 10), the result of Nielsen study (2003, p. 85 ), and the pre-calculated figures provided by Singapore

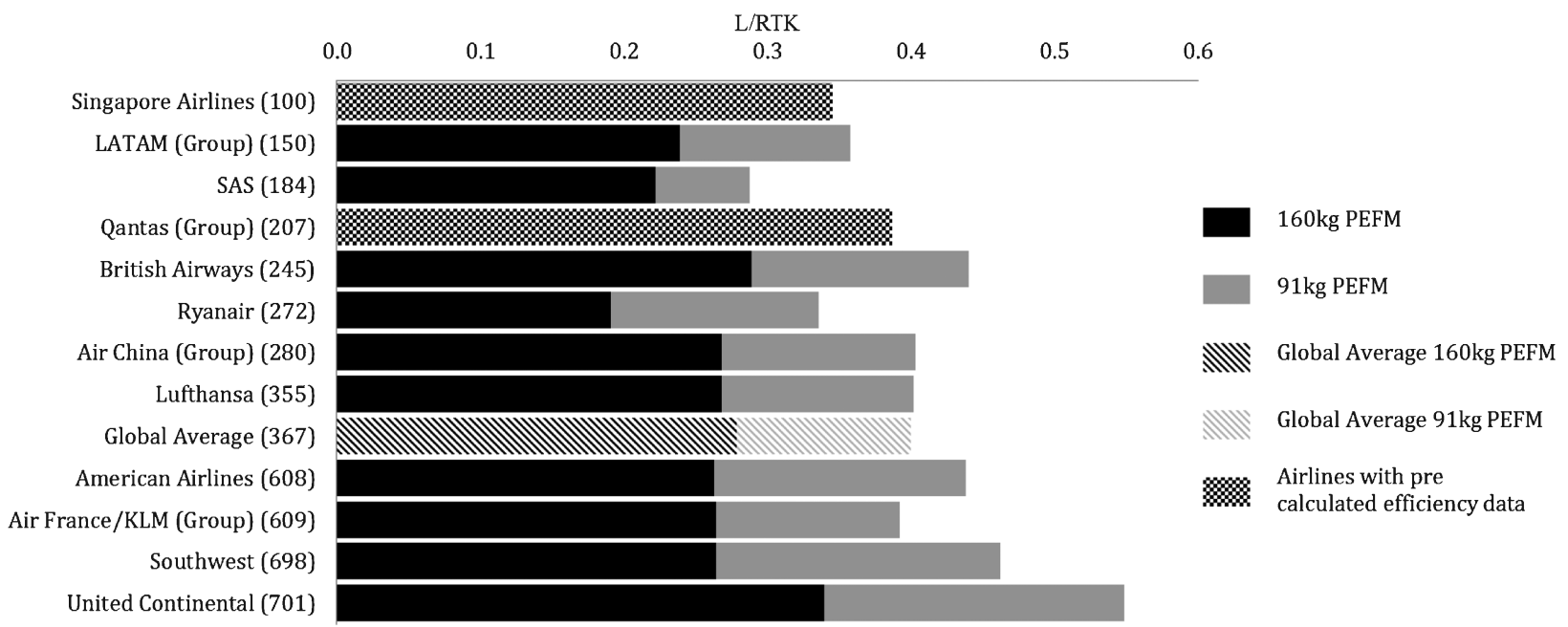

Figure 3. Airline fuel efficiency comparison by fleet size. (Note: Numbers following airline names represent size of respective airlines' fleet.) 


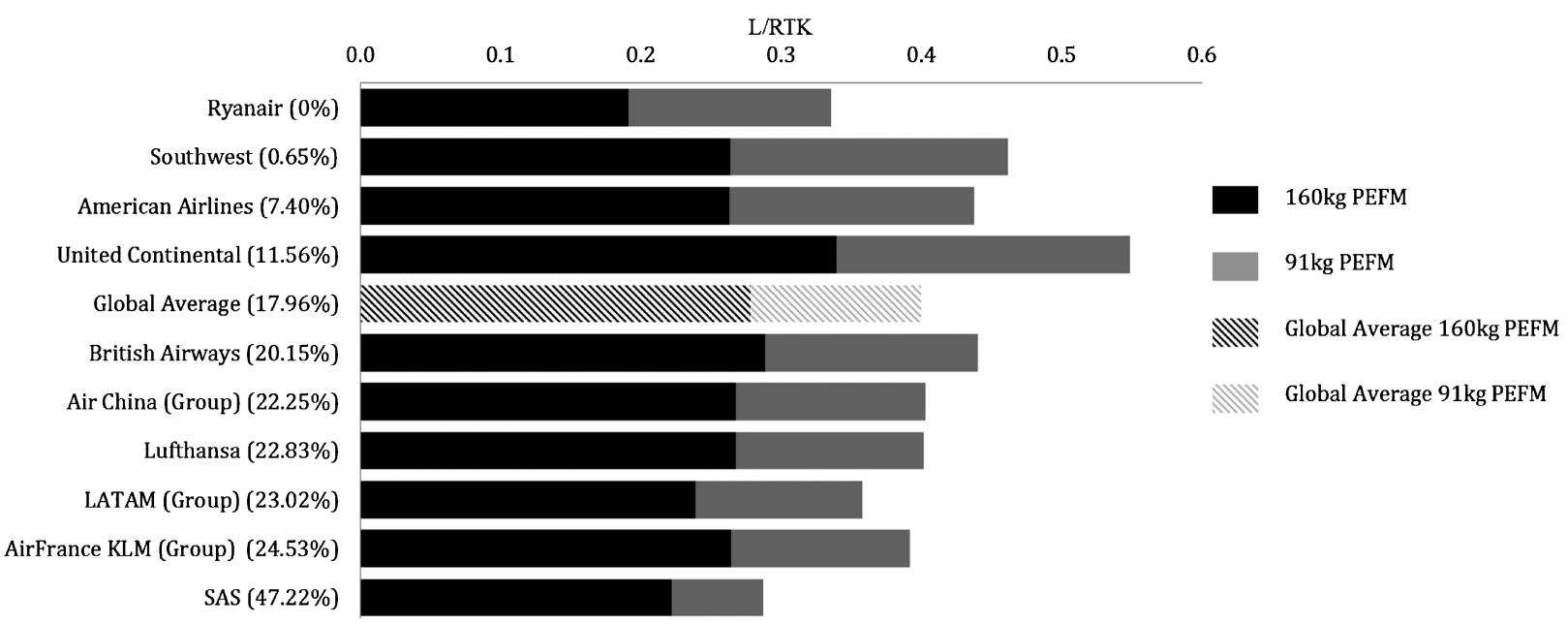

Figure 4. Fuel efficiency comparison by proportion of freight carriage in total traffic output. (Note: Percentages following airline names represent freight share of the total traffic output.)

Airlines and QANTAS (Group). When using the PEFM of $91 \mathrm{~kg}$, Qantas and Singapore Airlines were no longer "outliers" in terms of their fuel efficiencies, but were within $4 \%$ and $15 \%$ margin of the industry average, respectively. This suggests that using a PEFM of $91 \mathrm{~kg}$, which is the 2007 ICAO standard passenger weight, to convert passenger traffic volume to freight equivalent provides a calculation that more closely resembles practices of previous studies (Nielsen, 2003; Commonwealth of Australia, 2012).

As hypothesized, two low cost carriers in this study (RyanAir and Southwest) had better fuel efficiencies than their full service counterparts when using $160 \mathrm{~kg}$ PEFM in the calculation. However, when using $91 \mathrm{~kg}$ PEFM, fuel efficiencies of the selected low cost carriers were no better than those of full service carriers. This is due to the fact that when PEFM varied, only passenger equivalent freight mass is changed and not the mass of actual freight. The percentage of freight output in total traffic output for full service carriers is significantly higher than that for low cost carriers due to their different business models. Therefore, when the PEFM was increased, RTK (Total) of full service carriers did not increase as much as that of low cost carriers with a larger proportion of passenger equivalent freight. Additionally, the fact that using $160 \mathrm{~kg}$ PEFM to convert passenger transport will yield a larger freight equivalent suggests that freight transport, in general, has better fuel efficiency than passenger transport.

Meanwhile, it needs to be noted that this finding is limited by the relatively small sample size of the study. Also, using PEFM to convert passenger volume into freight volume is still a primitive approach as it uses a standard value to assess airlines of different business models and of different markets. Therefore, results based on this approach may not accurately capture airlines' actual output. However, it should be noted that studies on airline fuel efficiency are trying to estimate the actual efficiency using distinctive approaches. These studies all contribute to the body of knowledge in the field of energy efficiency and help airlines better understand the industry average.

Future studies should consider analyzing a larger sample size to better represent the global airline industry. In addition, a longitudinal study could be used to analyze fuel efficiency across an extended period in order to identify trends within individual airlines, as well as regional trends over time. To airlines, the authors recommend refocusing on fuel efficiency as not just the amount of fuel used per aircraft kilometer performed, but per revenue tonne kilometer. A more holistic and practical view in analyzing their performance will assist airlines' strategic planning as it encompasses a commercial aspect in load factor, as well as the operational arm represented in the fuel burn.

\section{References}

Air China Limited. (2012). 2011 annual report: Air China Limited. Retrieved from http://www.airchina.com.cn/www/en/html/index/ir/ financial_informatio/4069/2011h.pdf

Air France KLM Group. (2012a). Annual report 2011. Retrieved from http://www.airfranceklm-finance.com/en/Financial-information/ Annual-documents

Air France KLM Group. (2012b). Corporate social responsibility report 2011. Retrieved from http://www.airfranceklm-finance.com/en/ Financial-information/Annual-documents

Air Transport Action Group. (2013). Facts and figures. Retrieved from http://www.atag.org/facts-and-figures.html

American Airlines Corporation. (2012). Form 10-K 2011, pp. 22 \& 51, American Airlines Corporation, Retrieved from http://phx.corporate-ir. net/phoenix.zhtml?c $=117098 \& \mathrm{p}=$ irol-reportsannual $>$

ATAG--see Air Transport Action Group.

Berdowski, Z., Broek-Serle, F. N., Jetten, J. T., Kawabata, Y., Schoemaker, J. T., \& Versteegh, R. (2009). Recommended standard masses for updating EU safety regulations'. Survey on standard weights of passengers and baggage, pp. 88-92.

British Airways Plc. (2012). Annual report and accounts 2011. Retrieved from http://www.iagshares.com/phoenix.zhtml?c $=240949 \& \mathrm{p}=$ irolreportsannual

CASA. (1990). Civil Aviation Advisory Publication. (1990). No 235-1(1) Standard Passenger and Baggage Weights Subpart 15 Suggested 
Standard Passenger Weights, (Cwlth). Retrieved from http://www.casa. gov.au/wcmswr/_assets/main/download/caaps/ops/235_1.pdf

Commonwealth of Australia. (2012). Australia's latest fuel efficiency for aircraft operations, 2010-11. Managing the Carbon Footprint of Australian Aviation, Department of Infrastructure and Transport.

Grose, T. K. (2013). Reshaping flight for fuel efficiency: Five technologies on the runway. National Geographic, Retrieved from http://news. nationalgeographic.com/news/energy/2013/04/130423-reshapingflight-for-fuel-efficiency/

Hileman, I. J., Katz, J. B., Mantilla, J. G. \& Fleming, G. (2008). Payload fuel energy efficiency as a metric for aviation environmental performance. 26th International Congress of the Aeronautical Sciences, John A. Volpe National Transportation Systems Center, Massachusetts Institute of Technology, Cambridge, Massachusetts, 1-7.

Keisling, L. (2010, August 13). An economic analysis of comparative fuel economy? Knowledge Problem. Retrieved from http://knowledgeproblem. com/2010/08/13/an-economic-analysis-of-comparative-fuel-economy/

Kling, M. \& Hough, I. (2011). Air travel carbon and energy efficiency. Brighter Planet, San Francisco.

LATAM Airlines Group. (2013). U.S Securities Exchange Commission Form 20-F 2013. Retrieved from http://www.latamairlinesgroup.net/ phoenix.zhtml? $\mathrm{c}=81136 \& \mathrm{p}=$ irol-sec \&secCat01Enhanced.1_rs $=51 \&$ secCat01Enhanced.1_rc $=10 \&$ control_searchbox $=\&$ control_ selectgroup $=0>$

Lufthansa Group. (2012). Annual Report 2011. Retrieved from http:// investor-relations.lufthansagroup.com/fileadmin/downloads/en/ financial-reports/annual-reports/LH-AR-2011-e.pdf

McCartney, S. (2010). A Prius with wings vs. a guzzler in the clouds. The Wall Street Journal. Retrieved from http://online.wsj.com/article/ SB10001424052748704901104575423261677748380.html

Nielsen, S. K. (2003). Greenhouse gas emissions from international aviation and allocation options. Danish Environmental Protection Agency, Environmental Project Number 769.

Owen, B. (2008). Fuel efficiency development and prediction main thematic area: Climate change. Retrieved from http://www.cate.mmu. ac.uk/wp-content/uploads/2012/06/23-Fuel-development-andprediction.pdf
Peeters, P. M., Middel, J. \& Hoolhorst, A. (2005). Fuel efficiency of commercial aircraft: An overview of historic trends. NLR Nationaal Lucht-en Ruimtevaartianoratorium. The Netherlands, 12-35.

Qantas Airways Limited. (2011). Annual report 2011. Retrieved from http:// www.qantas.com.au/infodetail/about/investors/2011AnnualReport.pdf

Research and Innovative Technology Administration. (2013). Airline fuel cost and consumption (U.S. carriers - scheduled): January 2000 February 2013. Bureau of Transportation Statistics Research and Innovative Technology Administration. Retrieved from http://www. transtats.bts.gov/fuel.asp?pn=1

RITA-see Research and Innovative Technology Administration.

Ryanair Limited. (2012). Annual report \& financial statements 2011, pp. $3,6,67 \& 75$. Retrieved from http://www.ryanair.com/doc/investor/ 2011/Annual_Report_2011_Final.pdf

SAS Group. (2012a). Fast track to excellence: SAS Group annual report with sustainability overview 2012. pp. 21, 30 \& 91. Retrieved from http://www.sasgroup.net/SASGROUP_IR/CMSForeignContent/ 2012eng.pdf

SAS Group. (2012b). SAS Group sustainability report 2011. Scandinavian Airlines Pty Ltd, Stockholm, Sweden.

Singapore Airlines Co. (2012). Environmental report 2011/2012. pp. 19 \& 194. Retrieved from http://www.singaporeair.com/pdf/media-centre/ report2012.pdf

Southwest Airlines Co. (2011a). Performance by the numbers, Southwest Airlines One Report, Retrieved from http://www.southwestonereport. com/2011/\#!/financial/performance-by-the-numbers

Southwest Airlines Co. (2011b). 2011 annual report to shareholders, p. 34. Southwest Airlines Co.

United Continental Airlines. (2011). Form 10-K 2011, p. 33. U.S. Securities and Exchange Commission. Retrieved from http://www.sec. gov/Archives/edgar/data/100517/000119312512073010/d260625d10k. htm\#tx260625_8

Zeinali, M., Rutherford, D., Kwan I., \& Kharina, A. (2013). U.S. domestic airline fuel efficiency ranking 2010. Retrieved from http://www.theicct. org/sites/default/files/publications/U.S.\%20Airlines\%20Ranking\% 20Report\%20final.pdf 


\section{Appendix A: Sources of Data Used}

\begin{tabular}{|c|c|c|c|c|}
\hline \multirow[b]{2}{*}{ Airline } & \multicolumn{2}{|c|}{ Traffic Volume (Output) } & \multicolumn{2}{|c|}{ Fuel Consumption } \\
\hline & Passengers & Freight & Passengers & Freight \\
\hline Singapore Airlines & \multicolumn{4}{|c|}{ Annual report - Fuel efficiency directly reported RTK/unit of fuel (Year ending 31st March 2012) } \\
\hline Air China (group) & \multicolumn{4}{|c|}{ Annual Report (Year ending 31st December 2011) } \\
\hline Qantas (group) & \multicolumn{4}{|c|}{ Annual Report (Year ending 30th June 2011) } \\
\hline LATAM (group) & \multicolumn{4}{|c|}{$\begin{array}{l}\text { Annual Report } \\
\text { (Format is presented as 20-F of the US Securities and Exchange Commission) (Year ending 31st December 2012) }\end{array}$} \\
\hline Southwest Airlines & $\begin{array}{l}\text { Annual Report (Format is } \\
\text { presented as 10-K of the } \\
\text { US Securities and Exchange } \\
\text { Commission) (Year ending } \\
\text { 31st December 2011) }\end{array}$ & $\begin{array}{l}\text { RITA (Year ending } \\
\text { 31st December 2011) }\end{array}$ & \multicolumn{2}{|c|}{$\begin{array}{l}\text { Annual Report (Format is presented as } 10-\mathrm{K} \text { of the US } \\
\text { Securities and Exchange Commission) (Year ending 31st } \\
\text { December 2011) }\end{array}$} \\
\hline United Continental & \multicolumn{4}{|c|}{ Annual Report (Format is presented as 10-K of the US Securities and Exchange Commission) (Year ending 31st December 2011) } \\
\hline American Airlines & \multicolumn{4}{|c|}{ Annual Report (Format is presented as 10-K of the US Securities and Exchange Commission) (Year ending 31st December 2011) } \\
\hline Ryan Air & $\begin{array}{l}\text { Annual Report (Year ending } \\
\text { 31st March 2011) }\end{array}$ & Freight not carried & $\begin{array}{l}\text { Annual Report (Year ending } \\
\text { 31st March 2011) }\end{array}$ & Freight not carried \\
\hline British Airways & \multicolumn{4}{|c|}{ Annual Report (Year ending 31st December 2011) } \\
\hline Lufthansa & \multicolumn{4}{|c|}{ Annual Report (Year ending 31st December 2011) } \\
\hline $\begin{array}{l}\text { Air France KLM } \\
\quad \text { (group) }\end{array}$ & \multicolumn{2}{|c|}{ Financial report (Year ending 31st December 2011)* } & \multicolumn{2}{|c|}{$\begin{array}{l}\text { Corporate Social Responsibility Report } 2012 \text { (The report was } \\
\text { for the year ending 31st December } 2012 \text { but also included } \\
\text { fuel used for year ending 31st December 2011) }\end{array}$} \\
\hline SAS & \multicolumn{4}{|c|}{ Annual Report (Year ending 31st December 2011) } \\
\hline
\end{tabular}

*Report states that the financial year was changed from year ending March 31 to December 31, but a full year of data was reported for comparison purposes.

\section{Appendix B: Airline Performance Data}

\begin{tabular}{|c|c|c|c|}
\hline Airline & Fuel Consumption & RPK & RTK \\
\hline Singapore Airlines & & (L/RTK directly provided) & \\
\hline Air China (group) & $4,721,800,000 \mathrm{~kg}$ & $105,695,000,000 \mathrm{RPK}$ & $4,840,000,000 \mathrm{RTK}$ \\
\hline Qantas (group) & & (L/RTK directly provided) & \\
\hline LATAM (group) & $1,261,045,400$ USG & $96,081,200,000$ RPK & 4,597,800,000 RTK \\
\hline Southwest Airlines & $1,764,000,000$ USG & 97,582,530,000 RPM & $113,232,000$ RTM \\
\hline United Continental & $3,303,000,000$ USG & $126,491,000,000 \mathrm{RPM}$ & $2,646,000,000 \mathrm{RTM}$ \\
\hline American Airlines & $2,445,000,000$ USG & $126,491,000,000 \mathrm{RPM}$ & $1,783,000,000 \mathrm{RTM}$ \\
\hline Ryan Air & $682,200,000$ USG & $53,256,900,000 \mathrm{RPM}$ & Freight not carried \\
\hline British Airways & $5,500,000,000 \mathrm{~kg}$ & $117,348,000,000$ RPK & $4,739,000,000$ RTK \\
\hline Lufthansa & $9,023,671,000 \mathrm{~kg}$ & $200,376,000,000$ RPK & $9,487,000,000$ RTK \\
\hline Air France KLM (group) & $9,865,520,282 \mathrm{~kg}$ & $217,169,000,000 \mathrm{RPK}$ & $11,294,000,000$ RTK \\
\hline SAS & $1,351,410,934 \mathrm{~kg}$ & $24,839,000,000 \mathrm{RPK}$ & $3,555,000,000$ RTK \\
\hline
\end{tabular}

